\title{
Masterov Kliuch and the Early Upper Palaeolithic of the Transbaikal, Siberia
}

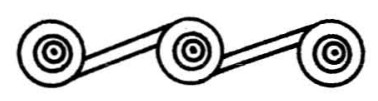

\author{
TED GOEBEL, MICHAEL R. WATERS, AND \\ MIKHAIL N. MESHCHERIN
}

Recent archaeological studies in Siberia and Central Asia have led to the recognition of a widespread early Upper Palaeolithic technocomplex that extended from Uzbekistan in the west to southeast Siberia in the east, between about 40,000 and 30,000 years ago (в.P.) (Derev'anko 1998; Derevianko and Petrin 1990; Goebel 1999; Goebel and Aksenov 1995; Goebel et al. 1993). This technocomplex is characterized by flat-faced core and blade technologies, and tool assemblages with retouched blades and flakes, end scrapers, burins, gravers, and unifacial points on blades (Goebel 1993; Kirillov 1987; Larichev et al. 1988, 1990). Bone and antler tools are common, as are pendants and other artifacts interpreted as body ornaments (Abramova 1989, 1995). The origins of this early Upper Palaeolithic technocomplex may lie in the preceding inner Asian Mousterian (Derev'anko 1998), or perhaps in the initial Upper Palaeolithic of southwestern Asia (Goebel 1993, 1999), best known from sites in Israel like Boker Tachtit and Kebara Cave (Bar-Yosef et al. 1992; Marks 1983). Whether this early Upper Palaeolithic technocomplex represents the emergence of anatomically modern humans in inner Asia is unclear, since diagnostic hominid fossils have not been found.

The eastern extent of the inner Asian early Upper Palaeolithic is the Transbaikal region of Siberia located east of Lake Baikal (Fig. 1). The early Upper Palaeolithic in this region is represented by a number of key sites, including Varvarina Gora, Tolbaga, Kamenka, and Masterov Kliuch, the subject of this study. In 1996 we initiated a joint Russian-American field program at Masterov Kliuch in order to provide more information about the early Upper Palaeolithic at its easternmost extent. Here we present details on site geomorphology, stratigraphy, and dating, and we characterize the site's cultural components, focusing on the lithic artifact assemblages. The data from Masterov Kliuch have important implications for understanding Palaeolithic site formation processes in Siberia, as well as early Upper Palaeolithic technology and raw material procurement.

Ted Goebel is with the Department of Anthropology, University of Nevada, Reno, NV; Michael Waters is with the Department of Anthropology, Texas A\&M University, College Station, TX; and Mikhail Meshcherin is with the Archaeological Laboratory, Chita Pedagogical Institute, Chita, Russia.

Asian Perspectives, Vol. 39, No. 1-2, (C) 2001 by University of Hawaii i Press. 


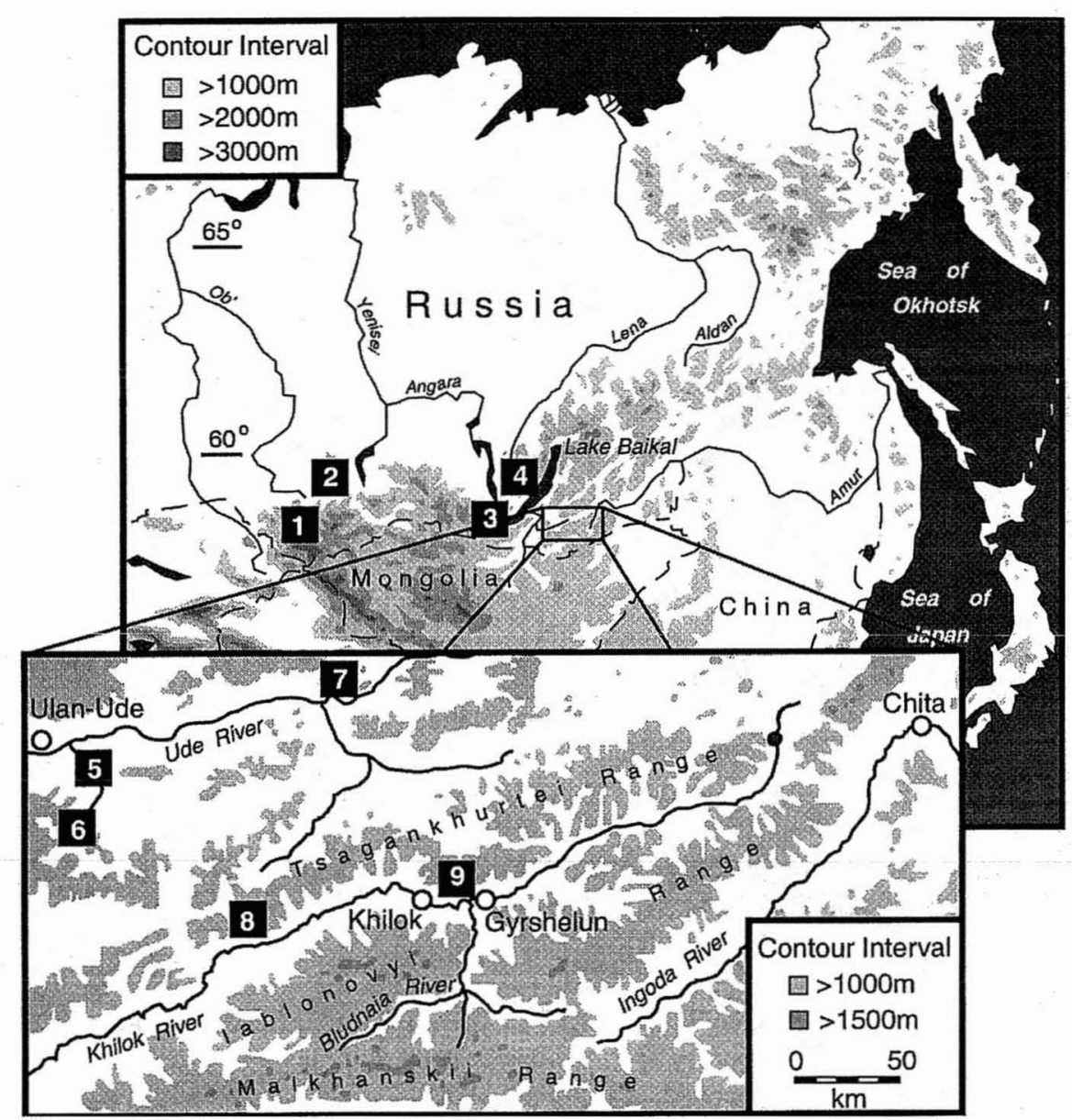

Fig. 1. Map showing location of Masterov Kliuch site and other early Upper Palaeolithic sites in Siberia. 1: Kara-Bom; 2: Malaia Syia; 3: Arembovskii; 4: Makarovo-4; 5: Kamenka; 6: Varvarina Gora; 7: Sannyi Mys; 8: Tolbaga; 9: Masterov Kliuch.

\section{SITE LOCATION AND HISTORY}

Masterov Kliuch is located along the Khilok River, $250 \mathrm{~km}$ west of the city of Chita, Chita Oblast', Russia (latitude $52^{\circ} 26^{\prime} \mathrm{N}$, longitude $110^{\circ} 35^{\prime} \mathrm{E}$ ) (Fig. 1). The site is situated on a southeast-facing bluff overlooking the broad Khilok River floodplain (Fig. 2). Today from this bluff, one can see the village of Gyrshelun, as well as the confluence of Gyrshelun Creek and the Khilok River, about $1 \mathrm{~km}$ to the east. Water flows from a small freshwater spring at the site; the Masterov Kliuch site is named after this spring. Natural vegetation in the immediate vicinity of the site is dominated by a well-established pine-larch taiga.

Meshcherin discovered the Masterov Kliuch site in 1990 (Meshcherin 1991). In 1990 and 1991, an area of about $30 \mathrm{~m}^{2}$ was excavated, uncovering two Palaeolithic components, as well as a Bronze Age component (Meshcherin 1996a, 1996b, 1996c; Meshcherin and Tuganov 1993). The lowest component (now called component I) yielded the densest concentration of cultural materials; among them were 


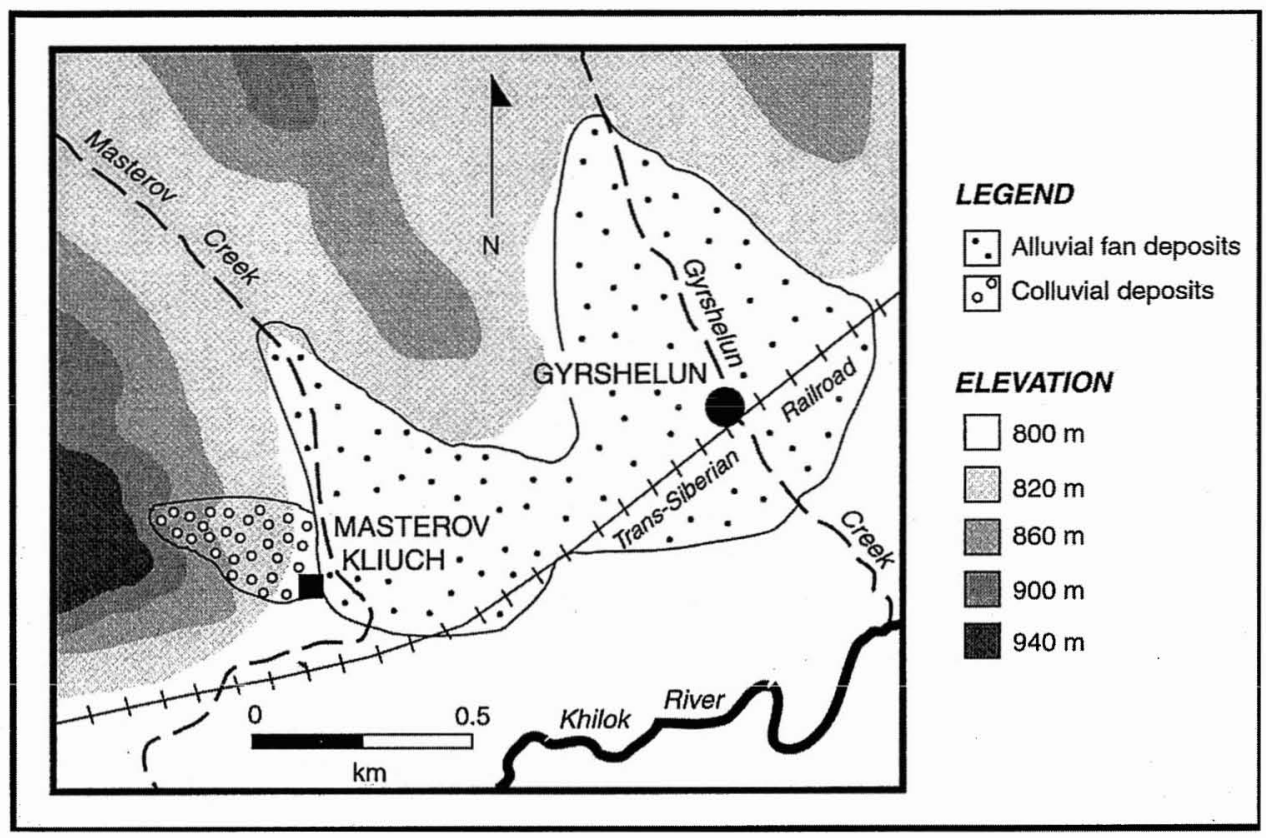

Fig. 2. The topographic and geomorphic setting of the Masterov Kliuch site.

lithic artifacts (i.e., large scrapers and knives made on blades) diagnostic of the Transbaikal early Upper Palaeolithic.

To further investigate the contexts and ages of Masterov Kliuch's cultural components, and to characterize its artifact assemblages, we conducted geoarchaeological research and controlled excavations in July-August 1996. An 8- $\mathrm{m}^{2}$ block was excavated to a depth of about $1.5 \mathrm{~m}$, adjacent to Meshcherin's earlier excavations situated along the edge of the bluff (Fig. 3). All artifacts and ecofacts encountered during excavation were precisely three-point provenienced, and all sediments from artifact-bearing deposits were screened through 1/8 in mesh (materials recovered from the screen were provenienced to $50-\mathrm{cm}^{2}$ horizontal quadrants and $5-\mathrm{cm}$ vertical intervals). In addition, trend and plunge of artifacts greater than about $20 \mathrm{~mm}^{2}$ in size were measured. Features and artifact concentrations were carefully mapped and photographed. Twelve geological probes and two $1 \times 2-\mathrm{m}$ test pits were also excavated to make stratigraphic comparisons across the site. Samples for geochronological, sedimentological, and palynological analyses were collected from the excavation as well as from an existing profile originally exposed by Meshcherin in 1990-1991.

\section{SITE GEOMORPHOLOGY AND STRATIGRAPHY}

Masterov Kliuch is situated within an apron of colluvial slope sediments on the east side of a steep hill next to the floodplain of Gyrshelun Creek (Fig. 2). Specifically, the site lies at the toe of the hillslope where the topography flattens (Fig. 3). A number of different stratigraphic units occur here; all are poorly sorted deposits of clayey sand to sandy clay. The following section describes the stratigraphic units; readers are referred to Waters (1992) for definitions of terms used to describe sediments. 


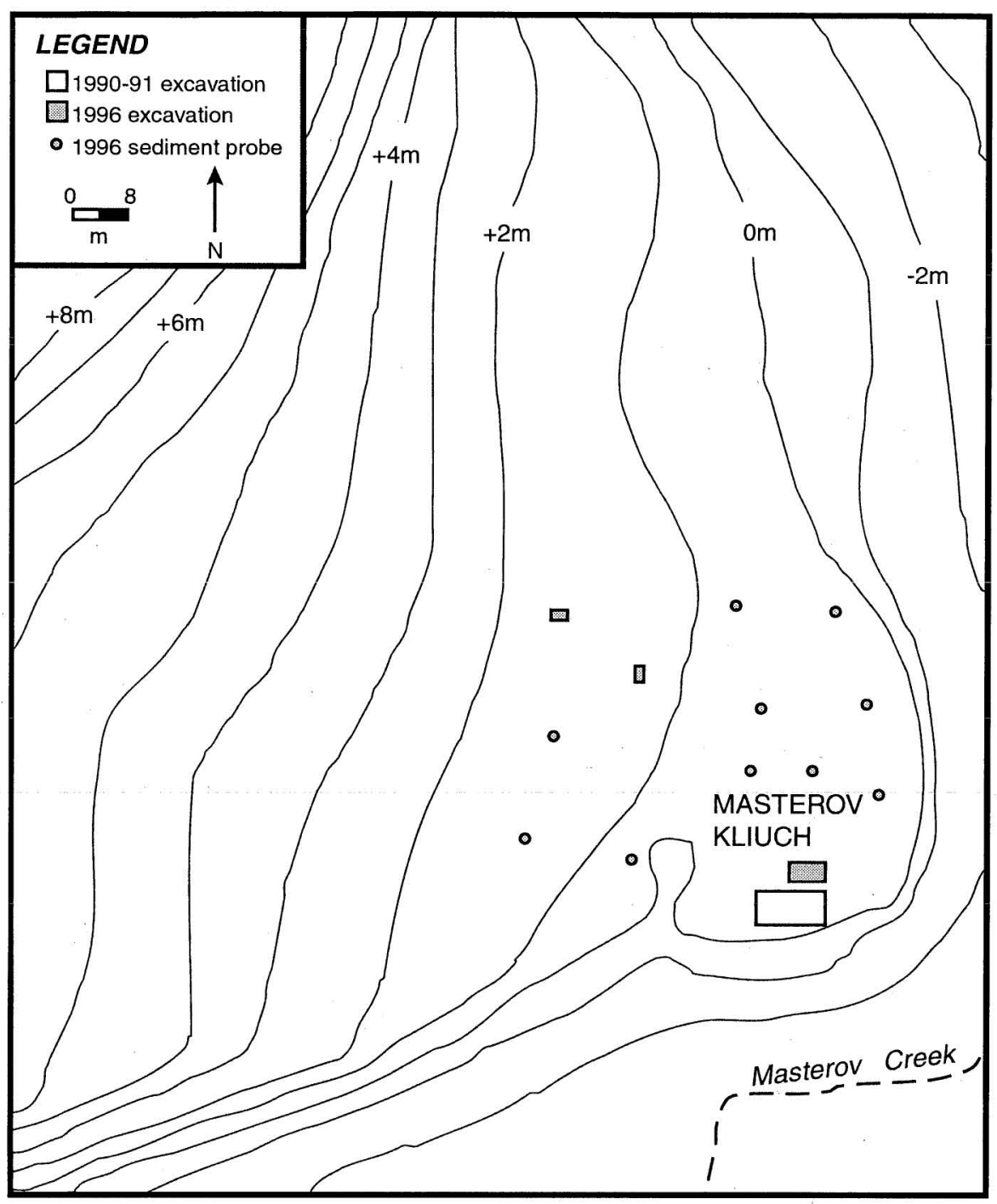

Fig. 3. The Masterov Kliuch site, showing locations of excavations.

Six unconsolidated late Quaternary stratigraphic units are present at Masterov Kliuch (Fig. 4). These were observed in the sidewall of Meshcherin's 1991 excavation that extended to a depth of $160 \mathrm{~cm}$. Unit 1 , at the base of the profile, is primarily a yellowish brown, poorly sorted, clayey sand with platy structure. There are a few layers of coarser sand within the unit that create three distinct fining-upward sequences. Also there is some calcium carbonate accumulation within this unit. Small frost cracks extend downward from the top of unit 1 . Unit 1 is unconformably overlain by unit 2 . At the base of unit 2 are several $10-\mathrm{cm}-$ thick lenses of clayey sand that appear to fill small channel depressions. This is overlain by a thick deposit of white-colored sandy clay with strong platy structure. Calcium carbonate is abundant in this unit. Coatings of this material on the sides of voids range from 0.5 to $1 \mathrm{~mm}$ thick, and fragments of calcium carbonate 


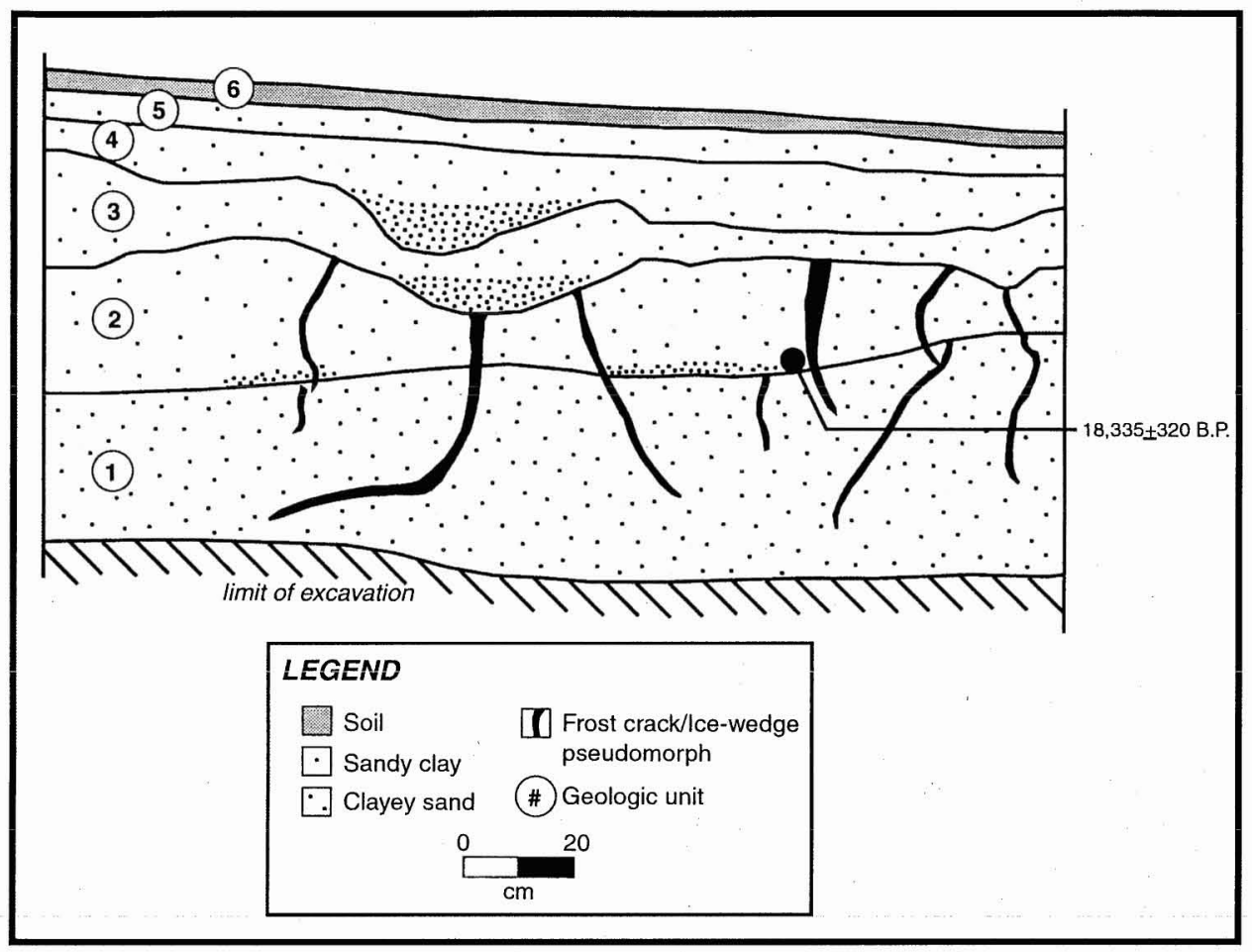

Fig. 4. Masterov Kliuch stratigraphic profile, along north wall of Meshcherin's 1991 excavation, re-exposed in 1996.

occur within the aggregates. The calcium carbonate in units 1 and 2 is pedogenic and indicates the presence of a Bk horizon. The presence of platy structure and calcium carbonate fragments within the aggregates indicates significant freezing and thawing of these sediments. Also, frost cracks and ice-wedge pseudomorphs extend from the top of unit 2 into unit 1 (Fig. 4). These cracks and wedges range from less than $2 \mathrm{~cm}$ to a maximum width of $7 \mathrm{~cm}$. When this layer was exposed in a horizontal profile polygonal cracking was evident.

An erosional contact separates unit 2 from the next overlying deposit (unit 3). The major portion of unit 3 is composed of yellowish brown, poorly sorted sandy clay. Clear evidence of small channel erosion is present in the profile: a series of shallow channels are filled with poorly sorted clayey sand. Unit 3 is separated from overlying unit 4 by another erosional unconformity. The main portion of unit 4 is composed of yellowish brown sandy clay with a distinct platy structure. At the base of unit 4, small shallow channels are filled with poorly sorted sand.

Unit 5 overlies unit 4 . Unit 5 is a brown, poorly sorted sandy clay with strong platy structure. This unit is in turn overlain by unit 6 , a dark gray sandy silt with strong platy structure. The organic-rich horizon at the top of unit 6 is the A horizon of the modern soil. Beneath this A horizon and extending into unit 5 to a depth of about 22 to $27 \mathrm{~cm}$ are reddish colored clayey lamelle that form discontinuous crenulated bands. These represent a weak cambic $(\mathrm{Bw})$ horizon of the modern soil. 
Based on field observations, textural analyses, and thin section analysis of sediment samples, the following scenario of geologic events is offered. First there was deposition of unit 1 by colluvial processes, followed by freezing and frostcracking. This was followed by a brief period of erosion and the deposition of unit 2 colluvium. After this, calcium carbonate translocated into these sediments and a $\mathrm{Bk}$ horizon formed. Cold temperatures affected these units as evidenced by the presence of small ice wedges and frost cracks, as well as the platy structure of the sediment, which probably resulted from ice lense formation. This was followed by erosion and deposition of unit 3 , and then erosion followed by deposition of unit 4. Sometime thereafter, units 5 and 6 were deposited by colluvial processes, and pedogenic processes created the thin $\mathrm{A}$ horizon and weak $\mathrm{Bw}$ horizon. All sediments have undergone repeated freezing and thawing.

\section{CULTURAL STRATIGRAPHY AND SITE FORMATION PROCESSES}

Three archaeological components are present at Masterov Kliuch. Component I is an early Upper Palaeolithic occupation occurring from 90-100 cm below the surface within geologic unit 2. Component II also appears to be an early Upper Palaeolithic occupation; it occurs within unit 4 at a depth of 30-60 cm below the surface. Component III is a Bronze Age occupation ranging in depth from $0-20 \mathrm{~cm}$ below the surface within units 5 and 6 . Given the complex geologic context of the Masterov Kliuch site, an important part of our research has been to establish the integrity of the site's Palaeolithic components, especially in terms of natural site deformation processes related to colluviation and cryoturbation.

Three indicators of site integrity-vertical distribution of artifacts, horizontal distribution of artifacts, and presence of conjoined artifacts-were studied in order to ascertain the degree of disturbance by colluvial processes. Vertical distribution of artifacts is shown in Figure 5. For components I and III, vertical distri-

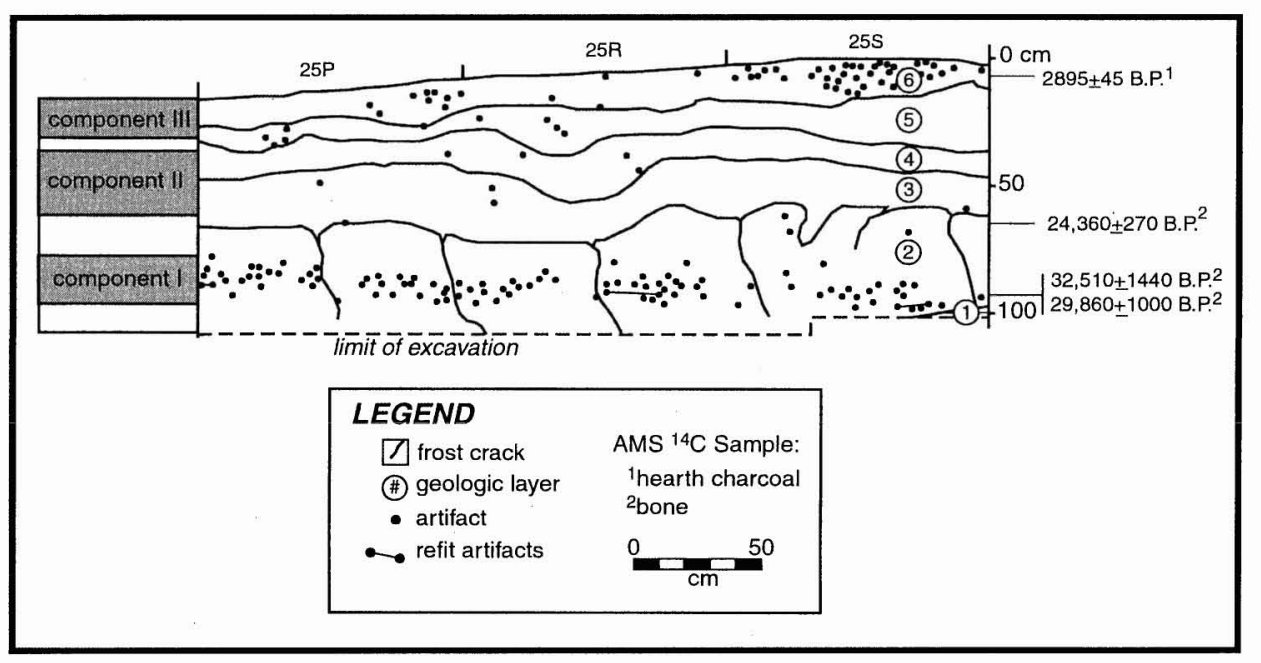

Fig. 5. Masterov Kliuch cultural stratigraphic profile, along south wall of 1996 excavation, showing locations of cultural components, vertical provenience of in situ finds, and radiocarbon age estimates on archaeological samples. 


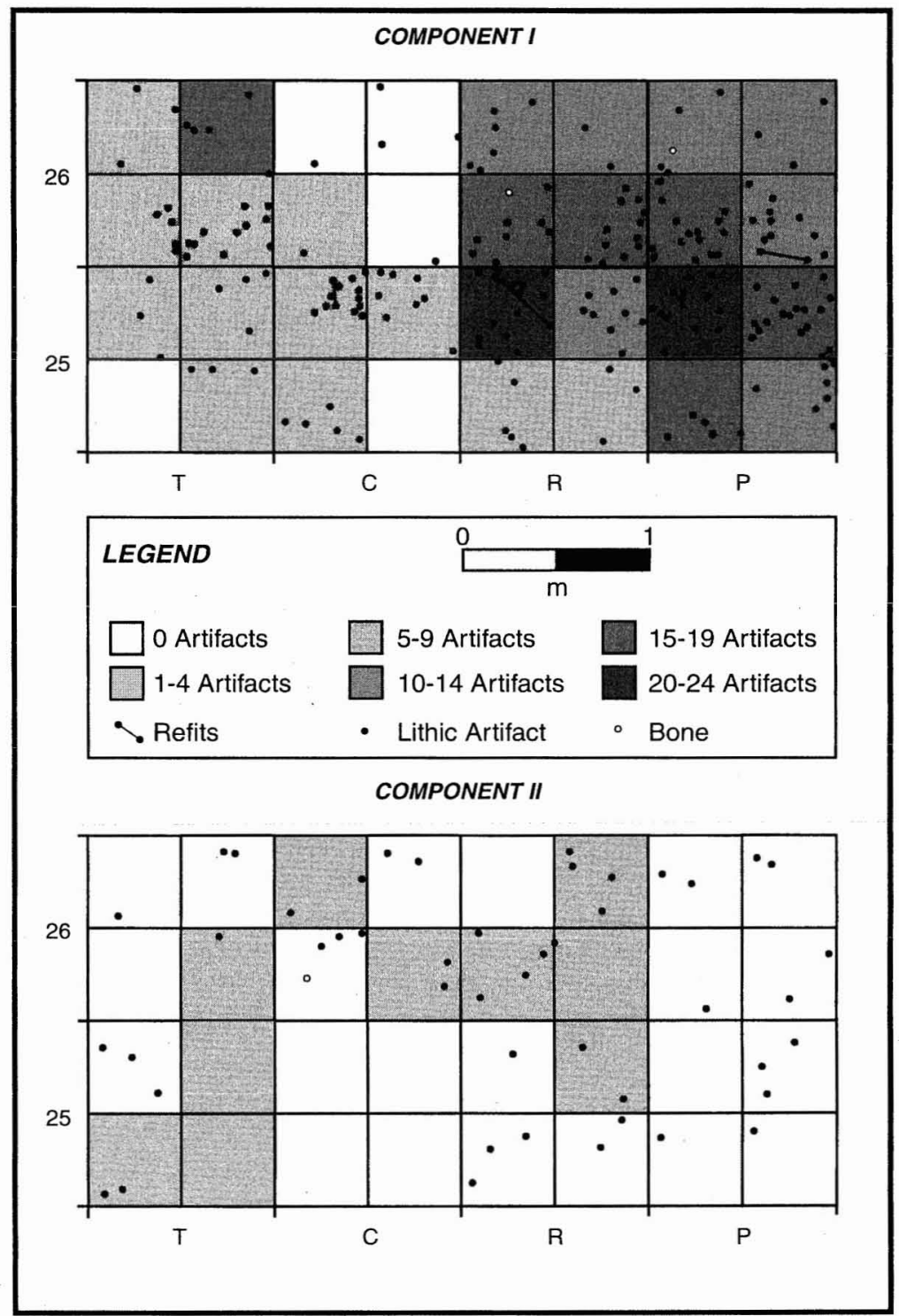

Fig. 6. Horizontal distributions of artifacts from components I and II at Masterov Kliuch, exposed in 1996, with shaded areas representing the frequency of artifacts found in situ and in sifted sediments, by $50-\mathrm{cm}^{2}$ quadrants.

bution of artifacts is relatively tight, with component I occurring within a $10-\mathrm{cm}-$ thick band and component III occurring within a 12-cm-thick band. A similar pattern can be seen in the horizontal distribution of artifacts from components I and III, with artifacts being situated in identifiable clusters across the excavation (Fig. 6). Further, 13 artifacts from component I were conjoined; the average horizontal distance between these conjoined artifacts is $20.25 \mathrm{~cm}$, and the average vertical distance is only $1 \mathrm{~cm}$ (Figs. 5 and 6). The tight vertical and horizontal distributions of artifacts, as well as the close horizontal and vertical proximity of 


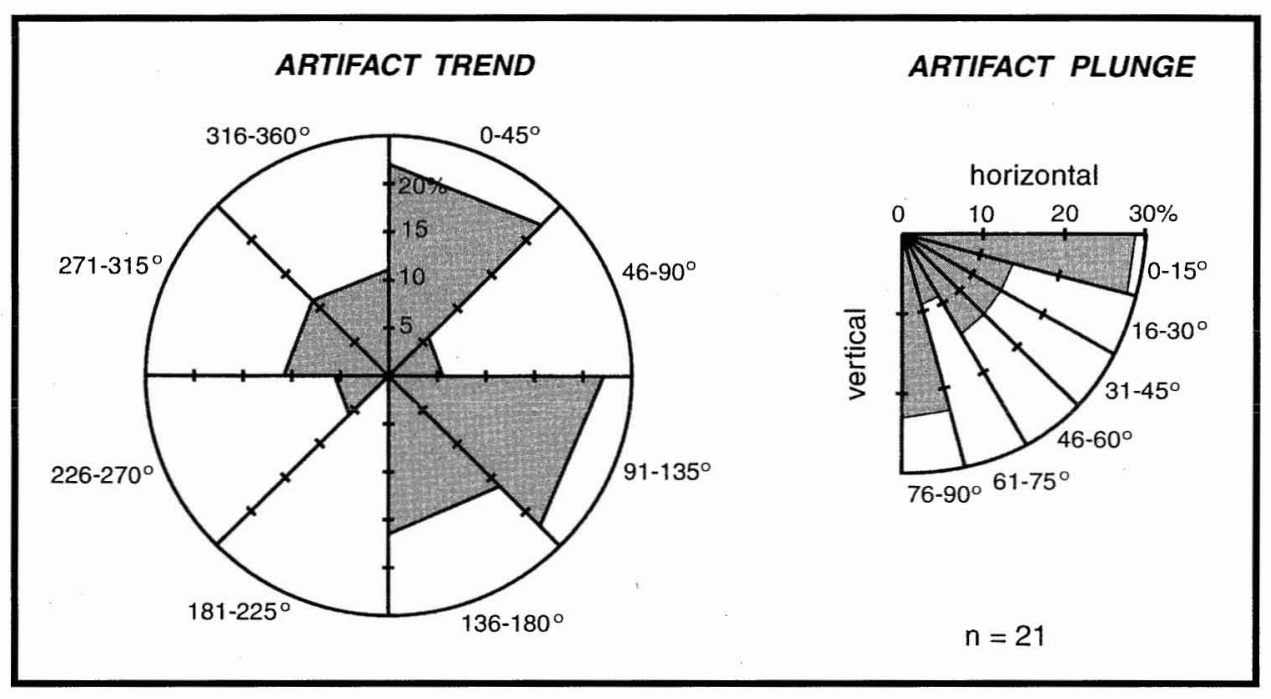

Fig. 7. Percentages of trend and plunge of artifacts measured from components I and II.

conjoined pieces, suggest that the artifacts of component I lie in a primary context. Component II artifacts, however, have a much greater vertical distribution than those in components I and III (component II has an average thickness of about $20 \mathrm{~cm}$ ), and the horizontal distribution of artifacts appears more scattered than in components I and III (Fig. 6). Further, no artifacts from component II could be conjoined. These data suggest that component II is redeposited.

Frost-heaving (the movement of artifacts due to repeated freezing and thawing of sediment) is also a factor affecting northern archaeological sites. To evaluate the degree to which freeze-thaw processes impacted the cultural components at Masterov Kliuch, we measured trend and plunge of all large-sized artifacts encountered in situ in the Palaeolithic components, using a Brunton pocket transit. Twenty-two such artifacts were analyzed in this way-16 for component I and 5 for component II (Fig. 7). Plunge measurements show that roughly half of the artifacts lie within $45^{\circ}$ of horizontal; that is, they lie more flat than upright. The other half lie more vertically upright, with plunge measures of between $45^{\circ}$ and $90^{\circ}$. Of these, only three artifacts have plunge measurements of $90^{\circ}$. Once reaching $90^{\circ}$ plunge, artifacts tend to move upward through the profile (Johnson and Hansen 1974; Wood and Johnson 1978). Thus, although frozen ground processes appear to have reoriented some artifacts, there is little indication that they have displaced them vertically. Trend measurements, further, show no obvious pattern in the direction that the artifacts plunge (Fig. 7), and few actually are trending along the slope of the site (about $100^{\circ}$ east of north), suggesting that artifacts of component I have been reoriented by minimal frost-action, but probably not slumping or slopewash.

The stratigraphic and provenience information from Masterov Kliuch show that while both Palaeolithic components lie in colluvial deposits, only component II is redeposited. Component I appears to lie in its primary place of deposition. Although frost-heaving has affected the orientations of the artifacts from compo- 
nents I and II, this process does not appear to have affected the locations of these artifacts.

\section{RADIOCARBON CHRONOLOGY AND AGE OF CULTURAL COMPONENTS}

Samples of bone $(n=3)$, tooth enamel $(n=1)$, charcoal $(n=1)$, and soil organics $(n=3)$ from the geological units and cultural components at Masterov Kliuch were dated through accelerator radiocarbon (AMS ${ }^{14} \mathrm{C}$ ) procedures. Charcoal was not well preserved in the site, occurring only in the uppermost unit in association with archaeological component III. For this reason, we concentrated on the dating of bone and other materials. When appropriately purified using XAD-2 resin, bone with significant amounts of intact collagen (typically greater than 5 percent of original amount of protein) can provide accurate age estimates (Taylor 1997). Pretreatment and AMS ${ }^{14} \mathrm{C}$ analysis of all samples was conducted at the NSF-Arizona AMS Facility, following standard methods described by Long et al. (1989) and Jull et al. (1983) for the AMS ${ }^{14} \mathrm{C}$ dating of bone and charcoal, respectively. Resulting AMS ${ }^{14} \mathrm{C}$ determinations (corrected for carbon-isotope fractionation) are presented in Table 1 . All dates are reported as uncalibrated.

Five radiocarbon ages were obtained from stratigraphic unit 2. Three samples of bone, one sample of tooth enamel, and one sample of organic matter were dated. The most reliable ages were derived on the three bone samples. Two of the bones were collected from archaeological component I during our excavations in 1996. These XAD-purified samples of bone (AA-23640 and AA-23641) had relatively high amounts of original protein (11.3 and 14.8 percent, respectively) and yielded ages of 32,510 \pm 1440 and 29,860 \pm 1000 B.P., which overlap at two-sigma. The other XAD-purified bone sample (AA-8888), which yielded an age of $24,360 \pm 270$ B.P., was collected from Meshscherin's 1991 excavation (Goebel 1993). This sample was collected from stratigraphic unit 2, but above archaeological component I and may be from a later brief occupation. These dates clearly indicate a pre-Sartan (pre-late glacial) age for unit 2 and that archaeological component I dates to roughly 30,000 B.P.

A pre-Sartan age for unit 2 is also supported by the frost cracks that extend from the top of this unit as well as the absence of frost cracking in overlying units. These frost cracks probably developed during the Sartan glacial period, as at other Upper Palaeolithic sites in the Baikal region (Bazarov et al. 1982; Tseitlin 1979). Thus, unit 2 and its associated archaeological component must pre-date the Sartan glacial period based on geologic evidence.

This geologic scenario is supported by a radiocarbon age on organic-rich sands found within a channel overlying the frost-cracked surface of unit 2 in a test pit $50 \mathrm{~m}$ to the northwest of the main 1996 excavation area (Fig. 3). Organic matter from this sand yielded an age of 18,850 \pm 135 B.P. (AA-23647). This organic material appears to have been derived from the erosion of soils that had developed on the slopes above the site.

Two aberrant ages were obtained from stratigraphic unit 2 . One small fragment of tooth enamel from archaeological component I yielded an age of 19,415 \pm 260 в.P. (AA-23642). Also, a small fragment of what was thought to be charcoal was collected near a frost crack in the sidewall exposure of Meshcherin's excava- 
Table i. Masterov Kliuch Accelerator Radiocarbon Age Estimates

\begin{tabular}{|c|c|c|c|c|c|c|}
\hline $\begin{array}{l}\text { VERTICAL } \\
\text { PROVENIENCE }\end{array}$ & $\begin{array}{l}\text { HORIZONTAL } \\
\text { PROVENIENCE }\end{array}$ & LAB NUMBER & MATERIAL & $\begin{array}{c}\text { AGE } \\
\text { DETERMINATION }{ }^{1} \\
\text { B.P. }(1 \sigma)\end{array}$ & $\delta^{13} \mathrm{C}$ & REMARKS \\
\hline Geologic unit 6 & Square $25-\mathrm{S}$ & AA-23648 & Hearth charcoal & $2,895 \pm 45$ & -25.9 & Archaeological component III \\
\hline Geologic unit 3 & Test pit & AA-23647 & Bulk soil organics & $18,850 \pm 135$ & -20.7 & $\begin{array}{l}\text { From organic rich sand lying } \\
\text { on top of unit } 2\end{array}$ \\
\hline Geologic unit 2 & 1991 excavation & AA-8888 & Bone & $24,360 \pm 270$ & -20.3 & $\begin{array}{l}\text { From possible cultural horizon } \\
\text { not noted in } 1996 \text { excavation }\end{array}$ \\
\hline Geologic unit 2 & Square $26-\mathrm{R}$ & AA-23641 & Bone & $29,860 \pm 1,000$ & -21.0 & Archaeological component II \\
\hline Geologic unit 2 & Square $26-\mathrm{P}$ & AA-23640 & Bone & $32,510 \pm 1,440$ & -19.3 & Archaeological component II \\
\hline Geologic unit 2 & Square $26-\mathrm{S}$ & AA-23642 & Tooth enamel (apatite) & $19,415 \pm 260$ & -18.4 & $\begin{array}{l}\text { Archaeological component } \\
\text { II-rejected }\end{array}$ \\
\hline Geologic unit 2 & Square $24-\mathrm{T}$ & AA-23643 & Organic material & $18,335 \pm 320$ & -23.2 & Base of unit 2-rejected \\
\hline Geologic unit 1 & Square $24-S$ & AA-23646 & Bulk soil organics & $7,630 \pm 65$ & -23.9 & Rejected \\
\hline
\end{tabular}

${ }^{1}$ Ages corrected for carbon-isotope fractionation. 
tion (Fig. 4). This sample yielded an age of 18,335 \pm 320 B.P. (AA-23643). These ages are at odds with the older bone-derived ages from component I and the geologic evidence.

There are several reasons why these younger ages are disregarded. The age of $19,415 \pm 260$ B.P. (AA-23642) was derived on the inorganic apatite fraction of the tooth. Apatite is notorious for yielding inconsistent results because a number of mechanisms can significantly alter carbon-isotope values in the apatite structure (Taylor 1987). The date of 18,335 \pm 320 B.P. (AA-23643) turned out not to be derived from charcoal, but instead from an aggregate of organic matter. We believe this aggregate most likely represents the post-depositional movement of an organic particle into unit 2 . Since this sample was collected only $2 \mathrm{~cm}$ from a visible crack, it may have been translocated into unit 2 from higher in the profile. As mentioned above, in some places on the site organic-rich sands dating to 18,850 B.P. are found overlying unit 2 . Both the date on organic matter from unit 2 and the date from the overlying organic-rich sand (in the nearby test pit) are statistically indistinguishable at one-sigma. It seems likely that a sample of this organic-rich sand was translocated downward through the profile via a frost crack into the underlying unit 2 . Thus, this age is considered invalid.

In an attempt to date geological unit 1, at the base of the profile, a bulk sample of soil organics from geologic unit 1 (taken from about $150 \mathrm{~cm}$ below surface) was AMS ${ }^{14} \mathrm{C}$ dated and yielded an age of $7630 \pm 65$ B.P. (AA-23646). This date is clearly too young based on the overlying dates from unit 2 and can be disregarded.

Stratigraphic units 3, 4, and 5, and archaeological component II are undated. Based on the organic-rich sand age and artifacts from component II, these appear to date to the late Upper Pleistocene, perhaps 18,000-10,000 B.P.

A sample of charcoal from a small hearth feature in component III near the top of the stratigraphic profile yielded an AMS ${ }^{14} \mathrm{C}$ age of $2895 \pm 45$ B.P. (AA-23648), providing support for the presumed late Holocene age of this cultural component.

Given these AMS ${ }^{14} \mathrm{C}$ determinations, as well as the above review of site stratigraphy and site formation processes, we can make the following conclusions about the age of the Masterov Kliuch sediments and cultural components. Unit 1 was deposited sometime prior to 30,000 B.P. The frost cracks and small ice-wedge pseudomorphs that originate along the upper contact of unit 1 perhaps formed during the Konoshchel'e cold snap, dated elsewhere to 33,000-31,000 в.P., or during some earlier stade of the early or middle Pleniglacial. Unit 2 and component I are AMS ${ }^{14} \mathrm{C}$ dated to about 30,000 B.P., the beginning of the LipovskoNovoselovo interstade (independently dated to $30,000-22,000$ B.P.). This is further supported by the extensive network of frost cracks and ice-wedge pseudomorphs that originate from the upper contact of unit 2; these probably formed during the height of the Sartan stade (22,000-17,000 в.P.). Unit 3 and component II have not been AMS ${ }^{14} \mathrm{C}$ dated, but, given their stratigraphic position above features relatively assigned to the last glacial maximum, as well as the platy structure of the sediment, must have been deposited (from upslope) sometime during the late glacial (17,000-10,000 в.P.). Units 4, 5, and 6 likely formed during the Holocene $(10,000$ B.P. to the present). Component III, found within units 5 and 6, dates to about 3000 B.P. and thus can be assigned to the Transbaikal Bronze Age. 


\section{ARCHAEOLOGICAL ASSEMBLAGES AND FEATURES}

The two Masterov Kliuch Palaeolithic components are described in detail below. Because it was not a focus of our study, the Bronze Age component is only briefly presented. For definitions of terms used to describe cores, tools, and other lithic artifacts, readers are referred to Andrefsky (1998) and Goebel (1993).

\section{Component I}

Cultural component I consists of a relatively dense band of lithic artifacts, with two distinct concentrations occurring in the $6-\mathrm{m}^{2}$ excavation, including a small cluster of flaking debris in the northwestern corner of the excavation (square $26 \mathrm{~T}$ ), and a larger cluster of retouched artifacts, cores, and flaking debris in the eastern half of the excavation (squares 25P, 26P, 25R, 26R) (Fig. 6). Within the latter cluster, two lithic technological activities are evident: (1) primary reduction activities represented by a concentration of 6 cores and about 60 cortical flakes, and (2) secondary reduction activities and tool use represented by a concentration of 18 retouched artifacts and nearly 30 retouch chips (Fig. 8). The few fragments of bone that were encountered during excavation of component I came from the

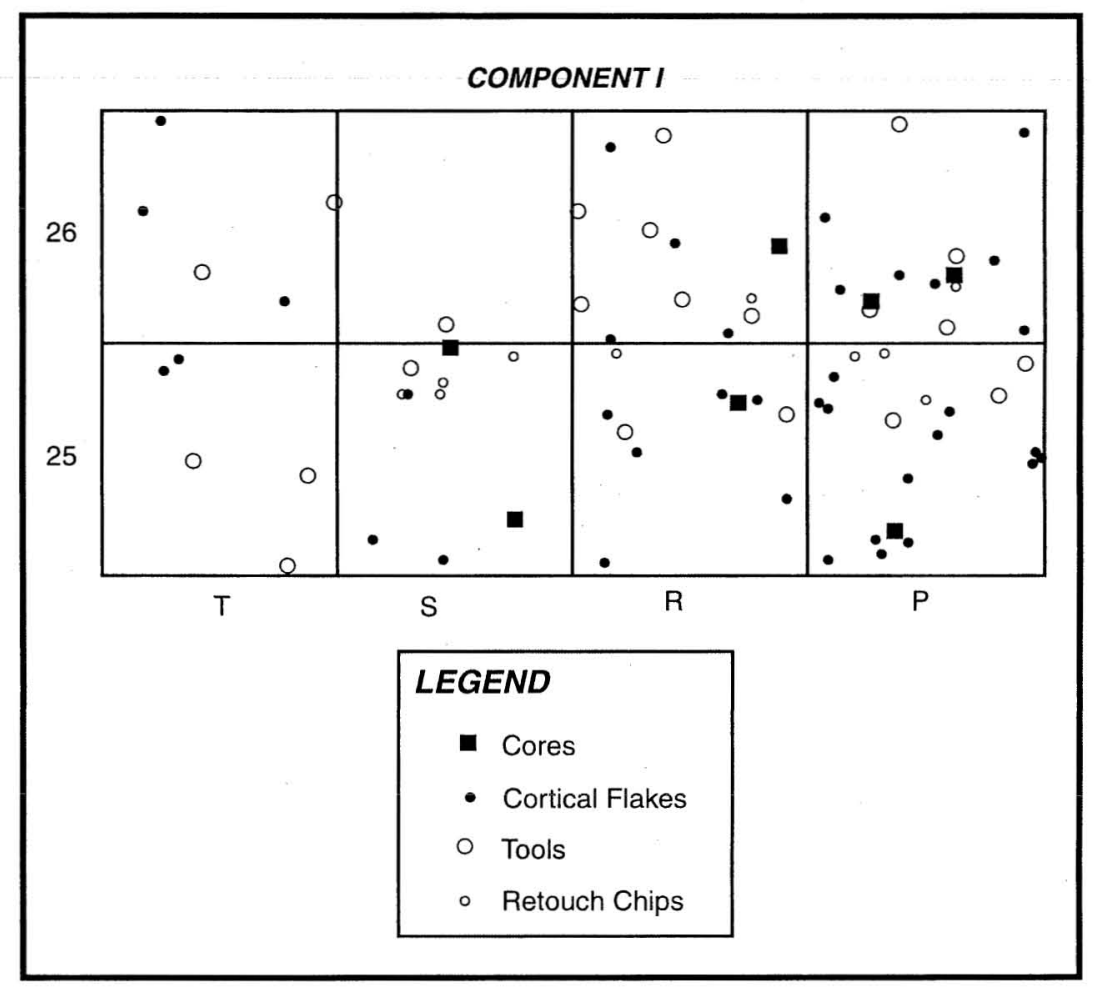

Fig. 8. Horizontal distribution of cores and cortical flakes (indicating area of primary reduction activities) as well as tools and retouch chips (indicating area of secondary reduction activities and tool use) for component I at Masterov Kliuch. 
eastern half of the excavation, in association with the concentrations of tools and retouch chips.

The component I assemblage consists of 367 pieces, including 360 lithic artifacts and 7 small bone fragments. Among lithic raw materials, dark gray cryptocrystalline silicate (ccs) dominates, making up 73 percent of the assemblage. Other materials include dark red ccs (11 percent) and speckled gray ccs (10 percent), while translucent tan/gray ccs (1 percent), brown ccs (1 percent), tan ccs (1 percent), and green ccs (1 percent) occur in low frequencies. There are also four splintered stones of clear quartz and two of clear quartzite that may be manuports. All of the ccs materials are available locally in alluvium of Gyrshelun Creek and the Khilok River.

The debitage assemblage (338 pieces) includes 7 cores, 66 cortical flakes, 179 flakes, 30 blades and blade fragments, 28 retouch chips, and 28 splinters (Fig. 9). Cortical flakes (making up 18 percent of the lithic assemblage) include 37 primary flakes, 24 secondary flakes, and 5 fragments. These are typically made on dark gray and speckled gray ccs (Fig. 9). Cortical flakes occur on every type of raw material present in the assemblage, further supporting the notion that raw materials were obtained locally. Further, the relative frequencies of raw material types are virtually the same for cortical flakes and noncortical flakes, indicating that unworked cobbles were carried to the site for reduction.

Core preparation and flake removal techniques were relatively expedient. The seven cores are informally prepared and include two monofrontal unidirectional flake cores made on cobbles of speckled gray ccs and dark gray ccs, a bifrontal bidirectional flake core made on a dark gray ccs cobble, a small end core (blades were struck from the end of the core rather than the face) made on a dark red ccs flake, a bipolar core made on a dark gray ccs flake, and two possible core tablets (platform rejuvenation spalls) on dark gray and speckled gray ccs. Platform surfaces were simply prepared, with 84 percent of all cores and their removals having smooth platforms, and 11 percent having cortical platforms. Trimming and grinding of platform edges is evident on 55 percent of debitage pieces.

Blades and blade fragments make up 9 percent of the debitage assemblage. No large blade cores, however, were encountered during our excavations in 1996, but earlier excavations by Meshcherin in 1996 did yield one obvious blade core from component I (Fig. 10m) (Goebel 1993). This is a unidirectional flat-faced blade core on dark gray ccs. Among the 21 tools, 11 are made on flakes or cortical flakes, indicating expediency in the production and selection of tool blanks. Nine tools are made on blades, and one, a chopper, on a cobble.

The presence of retouch chips in the debitage assemblage indicates that some secondary reduction activities also occurred at the Masterov Kliuch site. However, as with core preparation and blank manufacture, tool resharpening appears to have been expedient. Retouch invasiveness is minimal, with 14 of 22 tool edges having flake scars that extend less than $3 \mathrm{~mm}$ from the tool margin (Fig. 9). Only two artifacts have retouch scars that are greater than $10 \mathrm{~mm}$; these include a cobble chopper and denticulate.

The 22 tools in the assemblage include 8 retouched blades and blade fragments, 5 retouched flakes, 2 knives, 2 denticulates, 1 of each of the following: graver, notch, cobble chopper, possible burin spall, and combination tool (Fig. 10). Six 


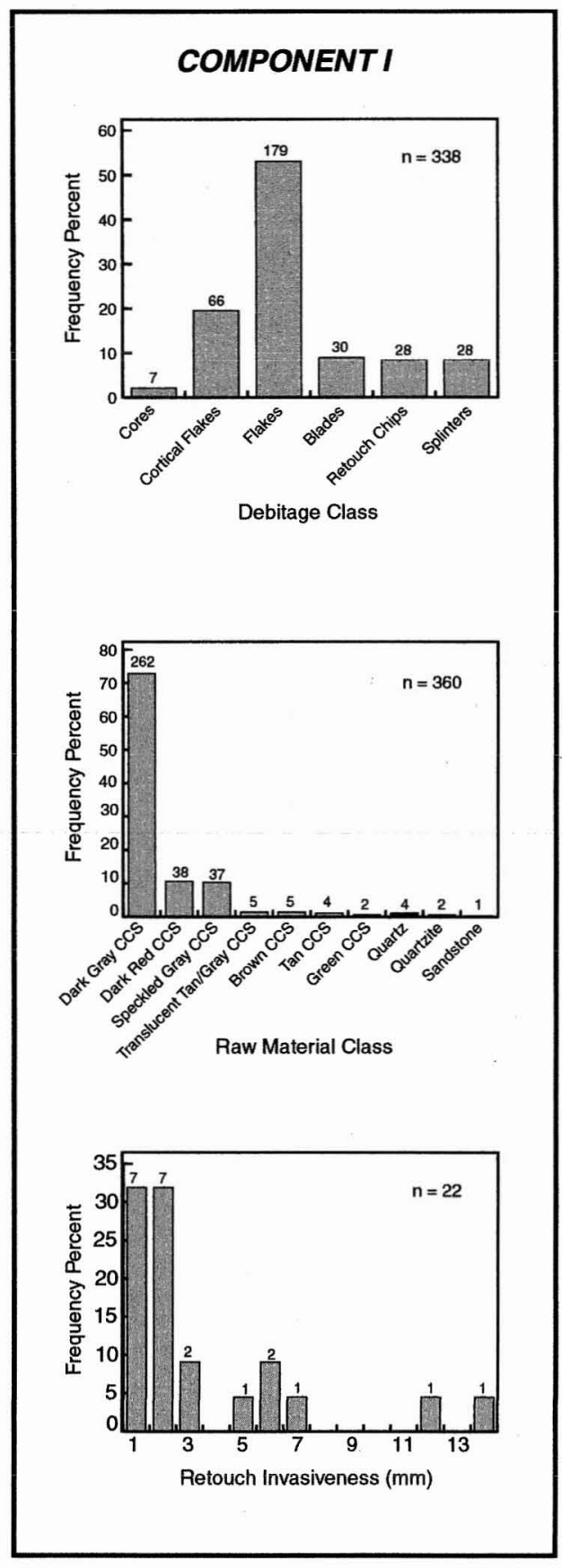

Fig. 9. Percentages of debitage classes and raw material classes, and distribution of retouch invasiveness, for component I at Masterov Kliuch.

of eight retouched blades are bilaterally retouched. Both knives are cortically backed, one on dark gray ccs and the other on dark red ccs. The graver has retouch that alternates between dorsal and ventral faces. The combination tool is an end scraper-knife on a dark red ccs cortical flake.

Faunal remains from component I (1991 and 1996 excavations) number 18 

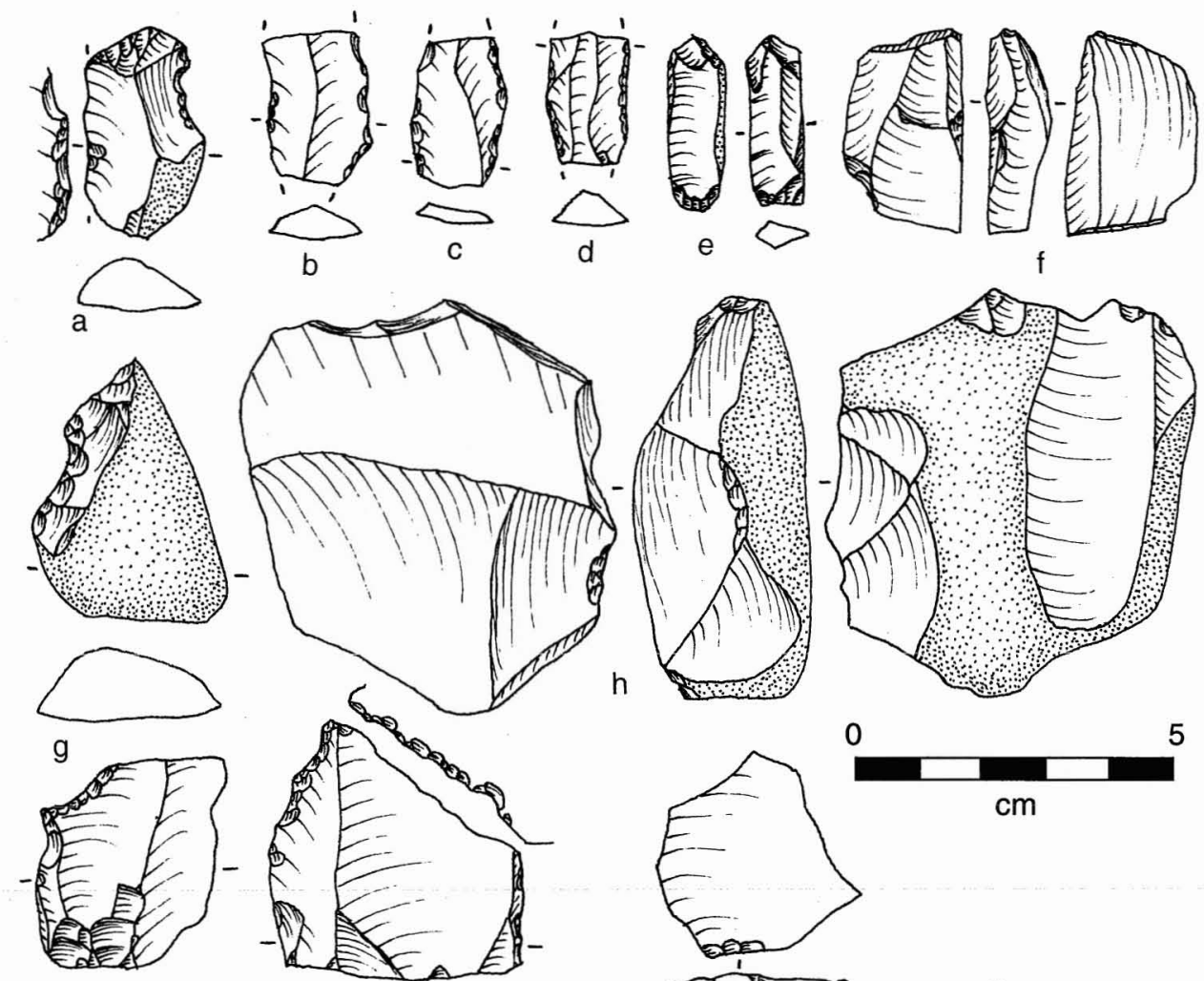

b
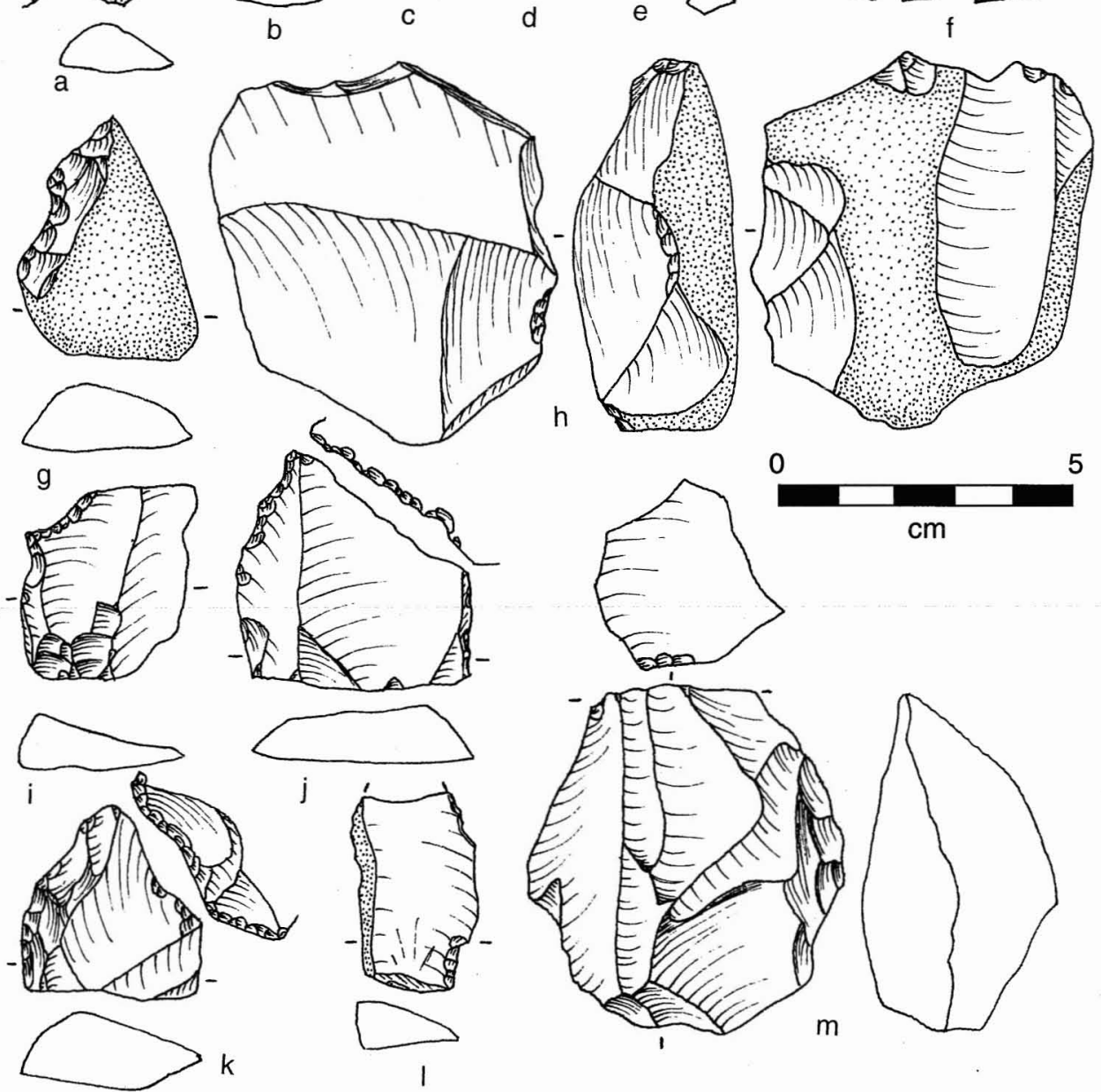

Fig. 10. Lithic artifacts from component I at Masterov Kliuch. a: end scraper-knife; b-d: retouched blades; e: bipolar core; f: end core; g: cobble chopper; h: bifrontal bidirectional core; i: graver; $j-k$ : denticulates; 1: cortically backed knife; m: unidirectional flat-faced blade core.

pieces. Identified taxa include horse/ass (Equus sp.), marmot (Marmota sp.), and large mammal (Mammalia gen. et sp. indet.) (Bakken 1997).

\section{Component II}

No features were encountered in component II, and, as described above, this component is considered to be redeposited and in a secondary position. The artifact assemblage from this component includes 104 lithic artifacts, 1 ceramic sherd, and 2 small unidentifiable bone fragments. The single ceramic sherd is an undec- 


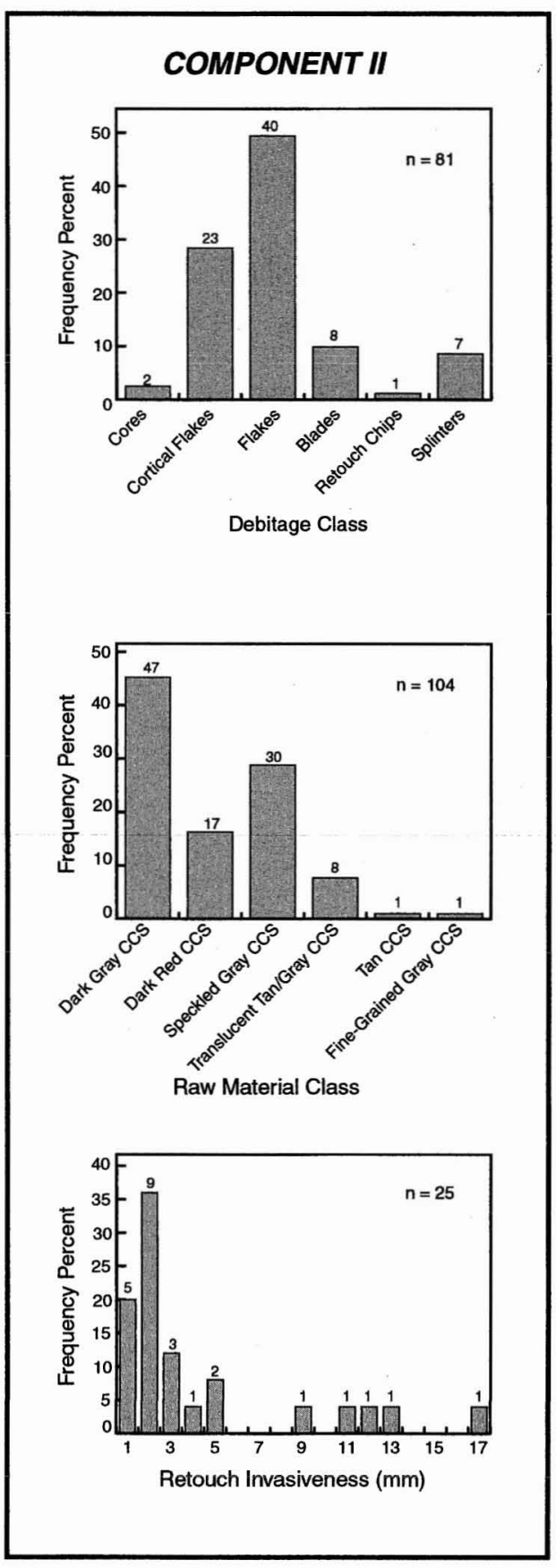

Fig. 11. Percentages of debitage classes and raw material classes, and distribution of retouch invasiveness, for component II at Masterov Kliuch.

orated dark gray body shard similar to those described for component III, and is probably intrusive from that overlying stratum.

The lithic artifact assemblage is made up of 81 debitage pieces and 23 tools. Raw materials include dark gray ccs (45 percent), speckled gray ccs (29 percent), dark red ccs (16 percent), translucent tan/gray ccs ( 8 percent), tan ccs ( 1 percent), and fine-grained gray ccs (1 percent) (Fig. 11). All but the last two raw materials 

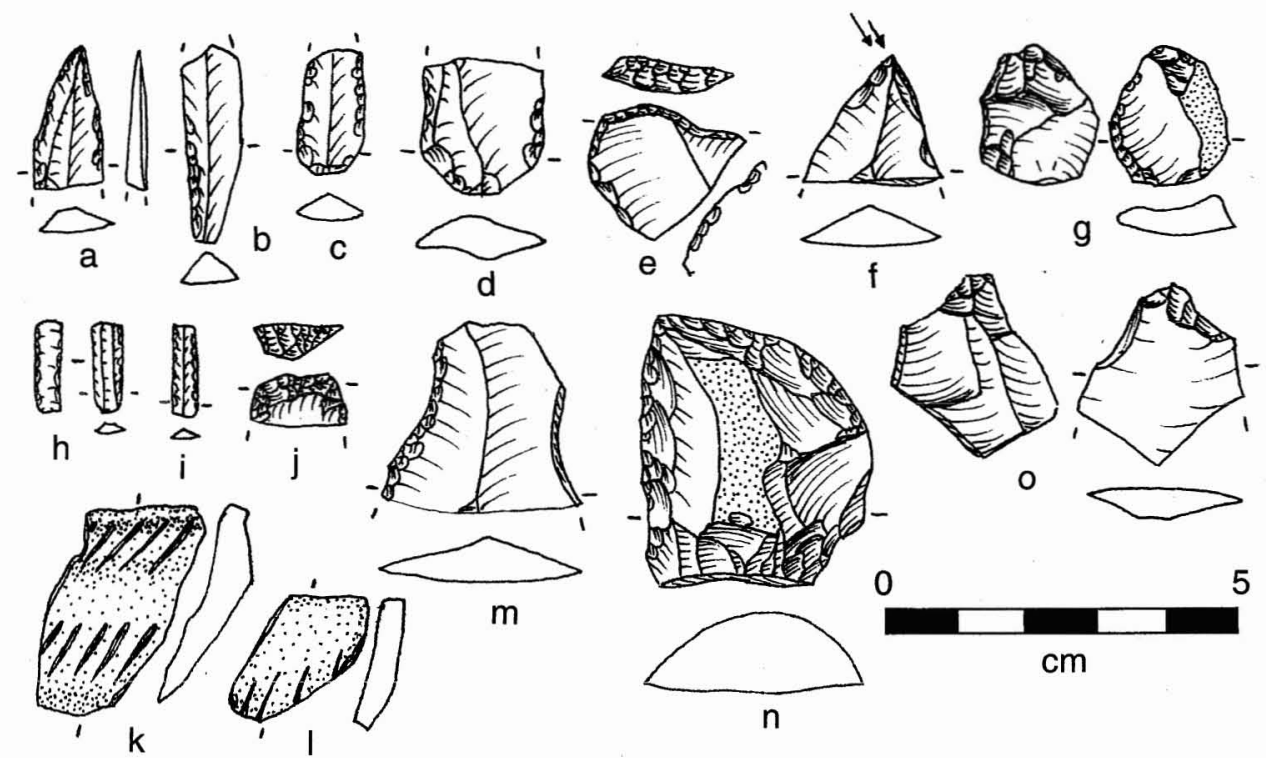

Fig. 12. Artifacts from components II $(\mathrm{a}-\mathrm{g}, \mathrm{m}-\mathrm{o})$ and III $(\mathrm{h}-\mathrm{l})$ at Masterov Kliuch. a: point on blade; b-c: retouched blades; d: retouched blade-like flake; e-j: end scrapers; f: burin; g-o: bipolar cores; $\mathrm{h}-\mathrm{i}$ : retouched microblades; $\mathrm{k}-\mathrm{l}$ : pottery shards; $\mathrm{m}$ : retouched flake; $\mathrm{n}$ : side scraper.

can be found in local creek and river alluvium. The debitage part of the assemblage includes 2 cores, 23 cortical flakes, 40 flakes, 8 blades, 1 retouch chip, and 7 splinters (Fig. 11). Both of the cores are small bipolar cores manufactured on translucent tan/gray ccs. Among the cortical flakes are 13 primary flakes, 9 secondary flakes, and 1 cortical flake fragment. Even though cores are for the most part absent from the assemblage, the high incidence of cortical flakes ( 28 percent of the debitage) indicates that primary reduction activities occurred frequently at the Masterov Kliuch site. Among 42 platforms scored, 17 percent are cortical, 76 percent are smooth, and 7 percent are dihedral, further indicating that minimal platform preparation was involved in the manufacture of these artifacts. Among blades, there are three proximal blade fragments, four medial blade fragments, and one complete blade. All of these are made either on dark gray or speckled gray ccs.

Among the 23 retouched artifacts, there are 7 retouched blades, 3 retouched flakes, 3 side scrapers, 2 notches, 2 denticulates, 2 possible burins, 1 cortically backed knife, 1 graver, 1 end scraper, and 1 pointed tool (Fig. 12). The retouched blades include one unilaterally and six bilaterally retouched pieces. The three side scrapers include a dejete scraper made on a dark gray ccs blade, a unilaterally retouched side scraper made on a speckled gray ccs cortical flake, and a side scraper fragment on a speckled gray ccs flake. Among the burins is a dark gray ccs blade fragment with a possible laterally burinated edge, as well as a dark gray ccs flake with a possible transversely burinated edge. The single pointed tool is made on a translucent tan/gray ccs blade fragment, and is dorsally retouched along both lateral margins. Retouch invasiveness is relatively low, with 17 (68 percent) of 25 measured tool edges displaying retouch scars that travel less than $4 \mathrm{~mm}$ from the tool margin. 


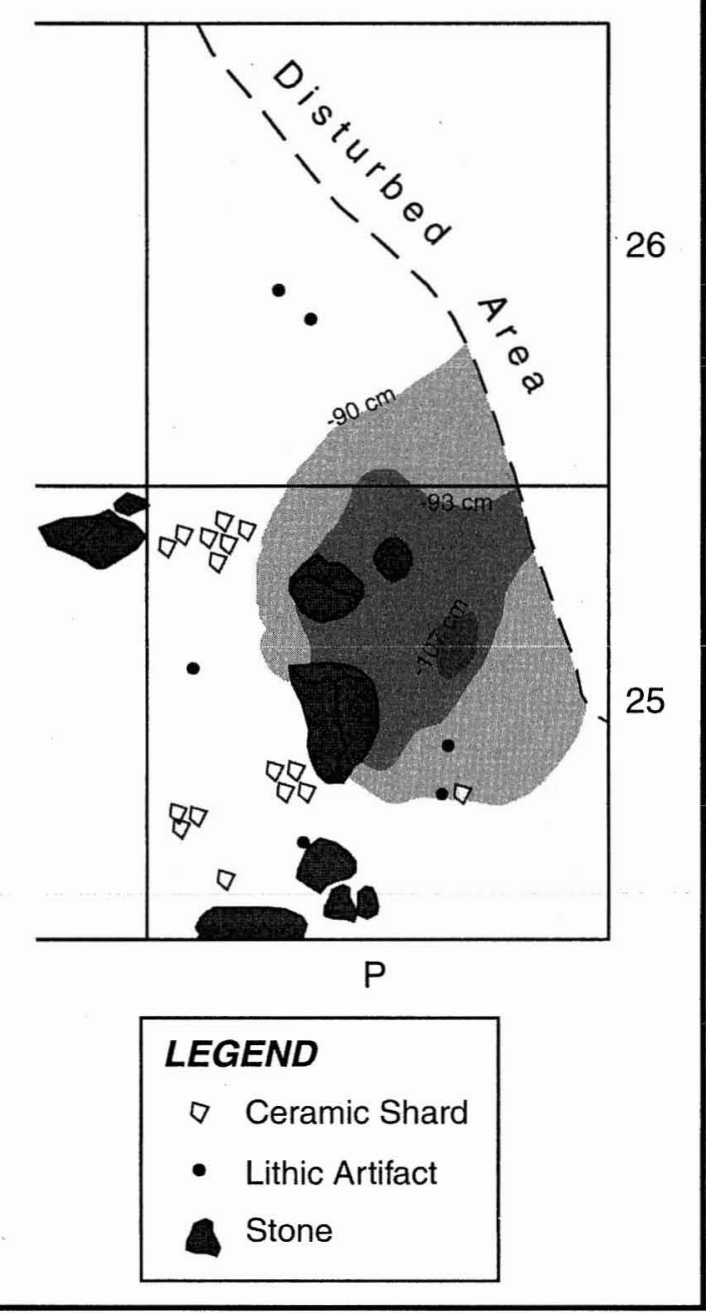

Fig. 13. Map of pit feature uncovered in 1996 in component III (shaded area increasing depth of floor of pit).

\section{Component III}

While not a focus of our study, excavations in 1996 uncovered an intact Bronze Age living floor with two preserved features: an unlined hearth and stone-lined pit. The hearth, occurring in square $25 \mathrm{~S}$ at an elevation of $76-82 \mathrm{~cm}$ below datum, consists of a wood charcoal and ash stain in an elongate oval shape, roughly $40-60 \mathrm{~cm}$ in diameter and $5 \mathrm{~cm}$ thick. A sample of the wood charcoal from this hearth yielded an AMS ${ }^{14} \mathrm{C}$ age estimate of $2895 \pm 45$ B.P. (AA-23648). The pit feature is situated in squares $25 \mathrm{P}$ and $26 \mathrm{P}$, about $2.5 \mathrm{~m}$ east of the hearth feature (Fig. 13). This 30-cm-deep pit is shaped like an inverted cone, with the top of the pit measuring about $100 \mathrm{~cm}$ in diameter, and the base only $10 \mathrm{~cm}$ in diameter. The pit's fill is an organic-rich loam with occasional charcoal flecks, small bone fragments, ceramic sherds, microblades, and several large stones.

The component III assemblage consists of 564 lithic artifacts (10 of which are 
tools), 23 ceramic sherds, and 12 small unidentifiable bone fragments (Fig. 12). Retouched artifacts include four retouched microblades, two retouched blades, two end scrapers, one notch, and one hammerstone. The ceramic sherds are all of the same type, but appear to represent at least two different vessels. These are poorly fired, dark-gray colored ceramics that range from about 4 to $6 \mathrm{~mm}$ thick. Decorations include bands of diagonal incisions that consistently measure about $10 \mathrm{~mm}$ long. Similar pottery styles have been identified at other sites in the Transbaikal with late Holocene components, including Studenoe, Ust'-Menza, and Altan (Bazarova et al. 1987; Konstantinov 1994). Radiocarbon ages on such sites range from about 3500 to 2000 B.P., and are commonly attributed to the Bronze Age (Konstantinov 1994).

\section{DISCUSSION AND CONCLUSIONS}

The Masterov Kliuch site contains two stratigraphically distinct early Upper Palaeolithic components. Component I has been accelerator radiocarbon dated to about 32,500-30,000 B.P., while component II has not been radiocarbon dated and appears to lie in a secondary context. Nonetheless, it too can be tentatively attributed to the early Upper Palaeolithic given technological and typological aspects of its lithic assemblage.

Lithic assemblages are characterized by blade and flake primary reduction technologies, with blade cores being either flat-faced or "end" cores (but not prismatic). Bipolar reduction strategies are also evident. Secondary reduction technologies include unifacial as well as burin techniques. Tool assemblages include retouched blades and flakes, end scrapers, gravers, burins, knives, denticulates, and notches. Component II also yielded a small unifacially worked point on a blade.

The core technologies and tool forms present at Masterov Kliuch are characteristic of the Siberian early Upper Palaeolithic, dated elsewhere to between about 42,000 and 30,000 B.P. at sites like Kara-Bom, Makarovo-4, Malaia Syia, Varvarina Gora, Kamenka, and Tolbaga (Bazarov et al. 1982; Goebel and Aksenov 1995; Goebel et al. 1993; Lbova 1996; Muratov et al. 1982). These sites in turn represent a widespread complex of flat-faced core and blade industries that spanned inner Asia from Uzbekistan in the west to the Transbaikal and perhaps inner Mongolia in the east during the mid-Upper Pleistocene, perhaps signaling the spread of anatomically modern humans from southwestern Asia (Brantingham 1999; Goebel 1993, 1999).

\section{Masterov Kliuch and Site Formation Processes in Siberia}

Nearly all early Upper Palaeolithic sites known from Siberia (e.g., Kara-Bom, Kamenka, Sannyi Mys, Varvarina Gora, Tolbaga) occur in cryoturbated colluvial deposits (Bazarov et al. 1982; Goebel et al. 1993; Lbova 1996; Okladnikov 1971); thus the geoarchaeological lessons learned at Masterov Kliuch have implications for these sites as well. Through careful excavation, three-point proveniencing of artifacts, conjoining artifacts, and measuring of trend and plunge of large artifacts found in situ, we were able to distinguish different degrees of integrity for the two early Upper Paleolithic components at Masterov Kliuch. Component I is characterized by tight vertical concentration and clustered horizontal distribution 
of artifacts suggesting a primary context, while component II is characterized by dispersed vertical and horizontal distributions of artifacts suggesting a secondary context. Further, while we were able to refit some artifacts from component I, no conjoinable artifacts were found in component II. Trend and plunge of artifacts in these components are quite variable, but few artifacts were vertically oriented, suggesting that frost-heaving had not significantly displaced artifacts.

Similar geoarchaeological studies are needed at sites like Kara-Bom and Makarovo-4 where artifact concentrations are thought to represent intact early Upper Palaeolithic living floors (Goebel and Aksenov 1994; Okladnikov 1983), and at sites like Tolbaga and Sannyi Mys where rings of stones are interpreted as dwelling features (Bazarov et al. 1982; Meshcherin 1985; Okladnikov 1971; Tseitlin 1979; Vasil'ev et al. 1987, 1993). Our experiences at Masterov Kliuch tell us that the behavioral context of artifacts at these sites, also situated in colluvial sediments along relatively steep slopes, could be disturbed, and that the putative dwelling features could be the product of natural, not cultural, processes. Clearly, reconstructions of early Upper Palaeolithic site structure and settlement behavior need to proceed with careful consideration of geologic site formation processes.

\section{Masterov Kliuch and Raw Material Procurement in the Siberian Early Upper Palaeolithic}

The analysis of the Masterov Kliuch lithic assemblages, although based on a relatively small sample, provides an interesting glimpse into early Upper Palaeolithic raw material selection and procurement. In component I, all lithic artifacts recovered in our excavations are made on raw materials that are available in nearby alluvium of Gyrshelun Creek and the Khilok River, within 2-3 km of the site. Debitage analysis suggests that early Upper Palaeolithic flintknappers carefully selected fine-grained cryptocrystalline-silicate nodules from these sources and carried them to the Masterov Kliuch site for flaking. Core preparation and blade and flake manufacture occurred on the site, as did tool use, resharpening, and discard. There is no evidence of finished tools being transported to the site from some other location, or of exotic raw materials being brought to Masterov Kliuch from more distant sources. Together, the evidence from component I suggests that early Upper Palaeolithic people were provisioning the Masterov Kliuch site exclusively with local raw materials for the manufacture of stone tools. The site, however, does not appear to have served solely as a task-specific quarry. Instead, evidence for multiple technological activities beyond those expected to be found at a quarry (Binford 1980; Binford and Binford 1966; Mellars 1996) suggests that Masterov Kliuch served more as a residential base than a specialized resource extraction site. Further, the provisioning of this place with only local resources (gathered within $3 \mathrm{~km}$ of the site) and the apparent absence of exotic resources indicate that raw material procurement was "embedded" within other foraging activities that were carried out in the immediate area surrounding the site (Binford 1979; Kuhn 1995; Odell 1996).

This pattern of raw material procurement has been noted at other early Upper Palaeolithic sites in Siberia. Most early Upper Palaeolithic sites, including Makarovo-4 in the upper Lena Valley (Goebel and Aksenov 1995; Medvedev et al. 1990), Arembovskii in the Angara Valley (Goebel 1993; Medvedev et al. 
1990), and Kara-Bom in the Altai Mountains (Derevianko et al. 1990; Goebel et al. 1993), are situated very near sources of abundant fine-grained cryptocrystalline silicates. In all of these cases, greater than 95 percent of all finished tools are made on local raw materials procured within $5 \mathrm{~km}$ of the sites, and the full technological sequence of primary and secondary reduction is represented for these local materials (Goebel 1993, 1999). Further, exotic raw materials are absent from these sites. Like at Masterov Kliuch, then, the lithic assemblages from these early Upper Palaeolithic sites represents embedded raw material procurement strategies that focused on "hyper-local" lithic resources.

Masterov Kliuch and most other Siberian early Upper Palaeolithic sites further appear to represent hunter-gatherer camps that were repeatedly occupied, perhaps because of their proximities to high-quality raw materials as well as because of their ecological settings in areas of high topographic relief and environmental zonation, where diverse animal and plant resources would have been regularly available (Goebel 1999). This pattern of early Upper Palaeolithic raw material procurement and settlement suggests that early modern human hunters of northern Asia were often "tethered" (Binford 1980; Kelly 1995) to locations on the landscape where lithic raw materials as well as diverse faunal resources were locally abundant and accessible. Similar patterns of raw material procurement and settlement have been documented for the Mousterian of southwest Europe (Mellars 1996) and the earliest Upper Palaeolithic complexes of Central Europe (i.e., the Bohunician and Szeletian) (Svoboda et al. 1996). In these areas, the transport of exotic raw materials and the more logistical procurement strategies that they represent did not appear until the emergence of the Aurignacian after 35,000 B.P. (Mellars 1996; Svoboda et al. 1996; White 1982). In Siberia, such behaviors appear to have emerged even later, sometime after 25,000 B.P. during the time of the "Mal'ta Culture," the region's middle Upper Palaeolithic complex (Goebel 1999). Perhaps this means that aspects of logistical organization and planning, so commonly portrayed to represent modern human behavior, were relatively late in developing among the Upper Palaeolithic hunter-gatherers of northern Asia.

\section{ACKNOWLEDGMENTS}

Our research at Masterov Kliuch and other Transbaikal Palaeolithic sites has been supported by the National Science Foundation (Archaeology and Archaeometry Program, SBR-9600664) and the Wenner-Gren Foundation for Anthropological Research. The authors wish to thank Deborah Bakken, Nancy Bigelow, Ian Buvit, Mikhail Konstantinov, James Johnson, Vladimir Petrov, Xanthe Robertson, Vasilii Tashak, and Sergei Vasil'ev for their assistance in the field and/or laboratory. Special thanks to Clint Cole, who contributed many hours entering data and producing charts and tables, to Lee Nordt, who assisted in the analysis of the micromorphology sediment samples, and to Tim Jull and Austin Long, who provided valuable assistance in interpreting radiocarbon age estimates.

\section{REFERENCES}

Abramova, Z. A.

1989 Paleolit severnoi Azii, in Paleolit Kavkaza i Severnoi Azii: 143-243. Leningrad: Nauka.

1995 L'art Paleolithique de l'Europe Orientale et de Siberie. Grenoble: Jerome Millon.

ANDREFSKy, WILLIAM JR.

1998 Lithics: Macroscopic Approaches to Analysis. Cambridge: Cambridge University Press. 
Bakken, Deborah A.

1997 Faunal material from Masterova Gora (1994 field season). Unpublished report.

Bar-Yosef, O., B. Vandermeersch, B. Arensburg, A. Belfer-Cohen, P. Goldberg, H. Laville, L. Meignen, Y. Rak, J. D. Speth, E. Tchernov, A-M. Tillier, and S. Weiner

1992 The excavations in Kebara Cave, Mt. Carmel. Current Anthropology 33:497-550.

Bazarov, D.-D. B., M. V. Konstantinov, A. B. Imetkhenov, L. D. Bazarova, and V. V. SAVINOVA

1982 Geologiia i Kul'tura Drevnikh Poselenii Zapadnogo Zabaikal'ia. Novosibirsk: Nauka.

Bazarova, L. D., L. V. Semina, and Iu. P. Surin

1987 Altan-mnogosloinyi pamiatnik pozdnego Antropogena Zabaikal'ia, in Prirodnaia Sreda $i$ Drevnii Chelovek v Pozdnem Antropogene: 167-179. Ulan-Ude: Akademiia Nauk SSSR, Sibirskoe Otdelenie.

BINFORD, LEwIS R.

1979 Organization and formation processes: Looking at curated technologies. Journal of Anthropological Research 35(3): 255-273.

1980 Willow smoke and dogs' tails: Hunter-gatherer settlement systems and archaeological site formation. American Antiquity 45:4-20.

Binford, Lewis R., ANd Sally R. Binford

1966 A preliminary analysis of functional variability in the Mousterian of Levallois facies. American Anthropologist 68(2):238-295.

Brantingham, P. JefFrey

1999 Astride the Movius Line: Late Pleistocene Lithic Technological Variability in Northeast Asia. Ph.D. diss. University of Arizona, Tucson.

Derev'anko, Anatoliy P.

1998 The Paleolithic of Siberia: New Discoveries and Interpretations. Urbana: University of Illinois Press.

Derevianko, A. P., And V. T. Petrin

1990 Stratigrafiia Paleolita iuzhnogo Khangaia (Mongolia), in Khronostratigrafia Paleolita Severnoi, Tsentral'noi, i Vostochnoi Azii i Ameriki: 161-173. Novosibirsk: Nauka.

Derevianko, A. P., Iu. V. Grichan, M. I. Dergacheva, A. N. Zenin, S. A. Laukhin, G. M. Levkovskaia, A. M. Maloletko, S. V. Markin, V. I. Molodin, N. D. Ovodov, V. T. Petrin, AND M. V. SHUN'KOV

1990 Arkheologiia i Paleoekologiia Paleolita Gornogo Altaia. Novosibirsk: Nauka.

GOEBel, TeD

1993 The Middle to Upper Paleolithic Transition in Siberia. Ph.D. diss. University of Alaska, Fairbanks. Ann Arbor: University Microfilms.

1999 Pleistocene colonization of Siberia and peopling of the Americas: An ecological approach. Evolutionary Anthropology 8(6): 208-227.

Goebel, Ted, AND Mikhail Aksenov

1995 Accelerator radiocarbon dating of the initial Upper Palaeolithic in southeast Siberia. Antiquity 69:349-357.

Goebel, Ted, Anatoli P. Derevianko, and Valerir T. Petrin

1993 Dating the Middle-to-Upper-Paleolithic transition at Kara-Bom. Current Anthropology $34: 452-458$.

Johnson, Donald L., and Kenneth L. Hansen

1974 The effects on frost-heaving on objects in soils. Plains Anthropologist 19:81-98.

Jull, A.J.T., D. J. Donahue, And T. H. Zabel

1983 Target preparation for radiocarbon dating by tandem accelerator mass spectrometry. Nuclear Instruments and Methods in Physics Research 218:509-514.

KELLy, ROBERT L.

1995 The Foraging Spectrum: Diversity in Hunter-Gatherer Lifeways. Washington, D.C.: Smithsonian Institution Press.

KIRILLOV, I. I.

1987 Tolbaginskaia Paleoliticheskaia kul'tura Zabaikal'ia i ee korreliatsiia s kul'turami sopredel'nykh territorii, in Drevnosti Sibiri i Dal'nego Vostoka: 68-73. Novosibirsk: Nauka. 
Konstantinov, M. V.

1994 Kamennyi Vek Vostochnogo Regiona Baikal'skoi Azii. Ulan-Ude-Chita: Rossiiskaia Akademiia Nauk, Sibirskoe Otdelenie.

Kuhn, Steven L.

1995 Mousterian Lithic Technology: An Ecological Perspective. Princeton: Princeton University Press.

LARICHEV, V. E., U. KHOL'USHKIN, AND I. LARICHEVA

1988 The Upper Paleolithic of northern Asia: Achievements, problems, and perspectives. I. Western Siberia. Journal of World Prehistory 2:359-396.

1990 The Upper Paleolithic of northern Asia: Achievements, problems, and perspectives. II. Central and eastern Siberia. Journal of World Prehistory 4:347-385.

LBova, L. V.

1996 Paleoliticheskoe mestonakhozhdenie Kamenka, in Novye Paleoliticheskie Pamiatniki Zabaikal'ia: 24-47. Chita: Chitinskii Gosudarstvennyi Pedagogicheskii Institut.

Long, A., A. T. Wilson, R. D. Ernst, And B. H. Gore

1989 AMS radiocarbon dating of bones at Arizona. Radiocarbon 31:231-238.

Marks, Anthony E.

1983 The Middle to Upper Paleolithic transition in the Levant. Advances in World Archaeology $2: 51-99$.

Medvedev, G. I., N. A. Savel'ev, And V. V. Svinin

1990 Stratigrafiia, Paleogeografia, i Arkheologiia Inga Srednei Sibiri: K XIII Kongressu INQUA 1990. Irkutsk: Nauka.

Mellars, Paul

1996 The Neanderthal Legacy: An Archaeological Perspective from Western Europe. Princeton: Princeton University Press.

MeshCHeRIN, M. N.

1985 Paleoliticheskie zhilishcha Zabaikal'ia, in Problemy Arkheologii Sibiri $i$ Dal'nego Vostoka: 20-22. Irkutsk: Irkutskii Gosudarstvennyi Universitet.

1991 Arkheologicheskaia razvedka v Khilokskom raione Chitinskoi Oblasti: otchet o polevykh issledovaniiakh $1990 \mathrm{~g}$. Unpublished report submitted to Institute of Archaeology, Leningrad.

1996 a Kharakteristiki industrii Pozdnekarginskogo-Rannesartanskogo vremeni zapadnogo Zabaikal'ia, in Pozdnii Paleolit Rannii Neolit Vostochnoi Azii i Severnoi Ameriki. Vladivostok: Institut Istorii, Arkheologii i Etnografii Narodov Dal'nego Vostoka.

$1996 b$ O nekotorykh osobennostiakh Verkhnepaleoliticheskikh industrii v Zabaikal'ia, in 100 Let Gunnskoi Arkheologii. Nomadizm Proshloe, Nastoiakshchee v Global'nom Kontekste i Istoricheskoi Perspektive: 48-51. Ulan-Ude: Rossiiskaia Akademiia Nauk, Sibirskoe Otdelenie.

1996c Nauchnyi otchet o polevykh issledovaniiakh v Khilokskom i Petrovsk-Zabaikal'skom raionakh Chitinskoi Oblasti v 1995 g. Unpublished report submitted to Tsentr po Sokhraneniiu Istoriko-Kul'turnogo Naslediia, Chita.

Meshcherin, M. N., And B. N. Tuganov

1993 Drevniaia stoianka u sela Gyrshelun, in Kul'tury i Pamiatniki Epokhi Kamnia $i$ Rannego Metalla Zabaikal'ia: 21-27. Novosibirsk: Nauka.

Muratov, V. M., N. D. Ovodov, V. A. Panychev, and S. A. Saforova

1982 Obshchaia kharakteristika Paleoliticheskoi stoianki Malaia Syia v Khakasii, in Arkheologiia Severnoi Azii: 33-48. Novosibirsk: Nauka.

Odell, GeOrge H.

1996 Economizing behavior and the concept of "curation," in Stone Tools: Theoretical Insights into Human Prehistory: 51-80, ed. George H. Odell. New York: Plenum Press.

OKLADNIKOv, A. P.

1971 Mnogosloinoe poselenie Sannyi Mys na R. Ude, v 35 km nizhe Khorinska, Buriatskoi ASSR (raskopki 1968 goda), in Materialy Polevykh Issledovanii Dal'nevostochnoi Arkheologicheskoe Ekspeditsii: 7-83. Novosibirsk: Nauka.

1983 Paleoliticheskaia stoianka Kara-Bom v Gornom Altae (po materialam raskopok 1980 goda), in Paleolit Sibiri: 5-20. Novosibirsk: Nauka.

Svoboda, Jiri, Vojen Lozek, and Emanuel VlCeK

1996 Hunters between East and West: The Paleolithic of Moravia. New York: Plenum Press. 
TAYLOR, R. E.

1987 Radiocarbon Dating: An Archaeological Perspective. Orlando: Academic Press.

1997 Radiocarbon dating, in Chronometric Dating in Archaeology: 65-96, ed. R. E. Taylor and M. J. Aitken. New York: Plenum Press.

Tseitlin, S. M.

1979 Geologiia Paleolita Severnoi Azii. Moscow: Nauka.

Vasin'ev, S. G., L. D. Bazarova, A. V. Konstantinov, and M. V. Konstantinov

1993 Paleoliticheskoe zhilishche na Sannom Myse: Kharakter i vozrast, in Kul'tury i Pamiatniki Epokhi Kamnia i Rannego Metalla Zabaikal'ia: 27-36. Novosibirsk: Nauka.

Vasil'ev, S. G, O. V. Kuznetsov, and M. N. Meshcherin

1987 Poselenie Tolbaga (novyi etap issledovanii), in Prirodnaia Sreda $i$ Drevnii Chelovek $v$ Pozdnem Antropogene: 109-121. Ulan-Ude: Nauka.

WATERS, Michael R.

1992 Principles of Geoarchaeology: A North American Perspective. Tucson: University of Arizona Press.

WHITE, RANDALL

1982 Rethinking the Middle/Upper Paleolithic transition. Current Anthropology 23:169-192.

WoOd, W. Raymond, AND Donald L. Johnson

1978 A survey of disturbance processes in archaeological site formation, in Advances in Archaeological Method and Theory, Vol. 1: 315-381, ed. M. B. Schiffer. New York: Academic Press.

\section{ABSTRACT}

In 1996, archaeological excavations were conducted at the Masterov Kliuch site, located east of Lake Baikal, Siberia. Three archaeological components were uncovered, all occurring in colluvial deposits. The two lower components (I and II) are Palaeolithic in age and character. Component $\mathrm{I}$ is an early Upper Palaeolithic industry dated to $32,500-30,000$ years ago (B.P.), and is in a primary context. Component II is undated but is also assignable to the early Upper Palaeolithic based on typology, although it appears to have been redeposited. Artifact assemblages from these two components are blade-based and include retouched blades and flakes, knives, denticulates, end scrapers, gravers, and burins. Component III represents a Bronze Age occupation dated to around 2900 B.P. The Palaeolithic industries at Masterov Kliuch are technologically/typologically similar to other initial Upper Palaeolithic industries in Siberia, and appear to represent some of the easternmost manifestations of an early Upper Palaeolithic technocomplex that spanned inner Asia from Uzbekistan to the Transbaikal between about 42,000 and 30,000 B.P. Our findings have further implications for Upper Palaeolithic research in northern Asia, especially regarding site formation processes and hunter-gatherer raw material procurement. First, like Masterov Kliuch, most early Upper Palaeolithic sites across northern Asia lie in colluvial settings and may not be in pristine, primary contexts, so that interpretations of stone features such as hearths or dwellings may be suspect. Second, study of the Masterov Kliuch lithic industries indicates that huntergatherers exclusively utilized local lithic resources in the manufacture of tools, and that raw material procurement strategies were embedded within other subsistence pursuits. This pattern of local, embedded raw material procurement is seen in virtually all other early Upper Palaeolithic sites in Siberia, while "logistical," longdistance procurement strategies, characteristic of the early Upper Palaeolithic of western Eurasia, did not appear in Siberia until much later in time, after about 25,000 B.P. Keywords: Siberia, early Upper Palaeolithic, geoarchaeology, lithic technology, raw material procurement. 